\title{
IN VITRO EVALUATION OF ERYTHROMYCIN IN CHLOROQUINE RESISTANT BRAZILIAN $P$. falciparum FRESHLY ISOLATES: MODULATING EFFECT AND ANTIMALARIAL ACTIVITY EVIDENCE
}

\author{
Carla M. S. MENEZES(1), Karin KIRCHGATTER(2), Sílvia M. F. DI SANTI(2), Carine SAVALLI(3), Fabíola G. MONTEIRO(3), Gilberto A. PAULA(3)
}

\& Elizabeth I. FERREIRA(1)

\begin{abstract}
SUMMARY
Erythromycin, a reversal agent in multidrug-resistant cancer, was assayed in chloroquine resistance modulation. The in vitro microtechnique for drug susceptibility was employed using two freshly isolates of Plasmodium falciparum from North of Brazil. The antimalarial effect of the drug was confirmed, with an $\mathrm{IC}_{50}$ estimates near the usual antimicrobial therapy concentration, and a significant statistical modulating action was observed for one isolate.
\end{abstract}

KEYWORDS: Erythromycin; Modulating effect; Antimalarial activity; Chloroquine $P$. falciparum resistance

\section{INTRODUCTION}

The multidrug resistance (MDR) is a phenomenon observed in neoplastic cells which have been shown to be resistant to structurally and functionally unrelated cytostatic agents. According to this mechanism, the resistance would be associated to the efflux of the drug from the cell, hindering the display of the therapeutic function. This efflux would result from the amplification of two genes, $m d r 1$ and $m d r 2$, and the consequent overexpression of an ATP-energy dependent protein, the P-glycoprotein, Pgp. Nevertheless, different hypotheses have been advanced based on the lower drug accumulation in resistant cells compared to sensitive ones, independently on the mechanism involved ${ }^{6,13}$.

In addition, calcium channel blockers, as verapamil, and other drugs as calmodulin antagonists, steroids and hormone analogues, and cyclosporins, in combination to an antineoplastic agent were shown to restore the sensibility level in resistant cells. These anti-MDR drugs were called reversal agents, chemosensitizers, or modulating agents, and have as a characteristic the ability of potentiating the antiproliferative activity of the chemoterapeutic agent in the resistant cells, having little or no influence on the sensitive ones ${ }^{13}$. This approach was further applied to human cancer therapy, leading to the search for the ideal modulating agent that should be deprived of intrinsic effect and toxicity ${ }^{4,13,26}$.

In 1987, MARTIN et al..$^{22}$ advanced the MDR mechanism hypothesis to explain the reversal of chloroquine $P$. falciparum resistance by verapamil. Although in vitro, in vivo and human assays have shown the usefulness of the combination of a modulating agent with chloroquine, there are many controversies about the MDR biochemical and genetic similarity in malaria. The antimalarial cross-resistance, the amplification and function of the plasmodio multidrug resistance genes, and the overexpression of a homologue protein to Pgp have been discussed. Also, the differences in chemosensitization mechanism and in the kinetics and mechanism of drug accumulation and release between the infected erythrocytes and mammalian multidrug-resistant cells have been considered $^{6,12}$.

The resistance reversal degree in malaria reports has been associated to the doses of the combined agent and to the resistance level of the strain. Higher doses of chlorpromazine and prochlorperazine were needed to reverse the in vitro chloroquine resistance in the highly resistant $P$. falciparum freshly isolates, although only a potentiation effect was observed in the most resistant isolate ${ }^{2}$.

Aiming the evaluation of the modulating effect in Brazilian chloroquine resistant $P$. falciparum strains, this paper reports the erythromycin behavior in two freshly isolates from the North of the country. Erythromycin was classified as a reversal agent in multidrugresistant cancer, specially for its lipophilicity ${ }^{16,17}$.

\section{MATERIALS AND METHODS}

The drugs used were chloroquine diphosphate (Fundação para o Remédio Popular) and erythromycin. For the microtechnique for drug susceptibility ${ }^{21,27}$, two freshly isolates of $P$. falciparum were employed: Isolate1 (SUCEN 198/94), from a woman with 6,600 asexual forms of

Financial Support: $\mathrm{CNPq}$

(1) Faculdade de Ciências Farmacêuticas, Universidade de São Paulo, São Paulo, SP, Brasil.

(2) Divisão de Programas Especiais, Superintendência de Controle de Endemias (SUCEN), São Paulo, SP, Brasil.

(3) Instituto de Matemática e Estatística, Universidade de São Paulo, São Paulo, SP, Brasil.

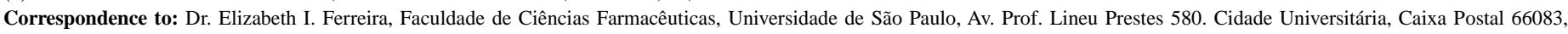
05389-970 São Paulo,SP, Brasil. 
parasites $/ \mathrm{mm}^{3}$ in her third malaria, and Isolate 2 (SUCEN 206/94), from a man in the second infection with 7,500 parasites $/ \mathrm{mm}^{3}$. These people were infected in the North of Brazil and had not been submitted to antimalarial treatment in the 14 or 28 days before the tests, as stated by $\mathrm{WHO}^{8}$.

\section{Microtechnique assay}

Twofold serial dilution of the drugs were used to titrate the plates. Chloroquine was employed in concentrations from 3.75 to $240.00 \mu \mathrm{g} / \mathrm{L}$ and erythromycin from 7.81 to $500.00 \mu \mathrm{g} / \mathrm{L}$, the average values corresponding to the respective therapeutic concentrations ${ }^{9,11}$. In a third plate, a fixed concentration of chloroquine $(30.00 \mu \mathrm{g} / \mathrm{L})$ was combined to the erythromycin series. The later is the plasma concentration effective against sensitive falciparum malaria ${ }^{3}$.

A $10 \%$ hematocrit solution of the infected blood was added to the plates. These were incubated according to the candle jar method ${ }^{31}$ at $37^{\circ} \mathrm{C}$ for 40 hours for Isolate 1 , and for 46 hours for Isolate 2 . Schizonts with three or more nuclei were counted in 200 parasites.

\section{Statistical analysis}

The statistical analysis comprehended the descriptive and the inferential studies of the data obtained ${ }^{7,10}$ and was carried out using the software S-Plus, version 4.5, and the Microsoft Excel for Windows, version 5.0.

In the descriptive analysis, the behavior of the parasitaemia rate as a function of the concentration was considered. The parasitaemia rate is the number of parasites in the different wells in relation to the controls. The fitting of statistical models to these lines was carried out in the inferential analysis. The logistic and log-log complement models were employed with the possibilities of coincident, parallel, and concurrent lines, the later with one or two intercepts. The $10 \%$ significance level was adopted for the likelihood ratio statistic, that in this case corresponds to the difference between 2 goodness-of-fit statistics. Then, the 50\% inhibitory concentration, $\mathrm{IC}_{50}$, of chloroquine, erythromycin, and their combination was estimated.

Table 1

Estimated median inhibitory concentration of chloroquine, erythromycin, and the respective combination on P. falciparum in vitro

\begin{tabular}{lccc}
\hline Drug & Isolate & $\begin{array}{c}\ln \mathrm{IC}_{50} \\
(\mu \mathrm{g} / \mathrm{L})\end{array}$ & $\begin{array}{c}\text { Confidence } \\
\text { interval } \\
(95 \%)\end{array}$ \\
\hline Chloroquine & 1 & 3.96 & $3.42 ; 4.50$ \\
\hline Erythromycin & 2 & 3.72 & $3.13 ; 4.31$ \\
\hline Chloroquine + Erythromycin & 1 & 4.30 & $-0.30 ; 8.91$ \\
& $2 *$ & 3.31 & $-2.70 ; 3.90$ \\
\hline
\end{tabular}

* same values (coincident lines)

\section{RESULTS}

The parasitaemia rate decreased as the concentration increased, as observed in the individual drugs and their combination in both isolates (Figures 1 and 2). These figures also illustrate the standard errors for the parasitaemia rate. The antiplasmodial effect of chloroquine only occurred in higher concentrations. The isolates could be classified as resistant, since the parasite growth was observed in concentrations higher or equal to $5.7 \mathrm{pmol} /$ well $(36.47 \mu \mathrm{g} / \mathrm{L})^{8}$. Erythromycin displayed antimalarial activity even in the first concentration assayed, which is eight times lower than the usual antimicrobial therapy ${ }^{9,11}$. The respective $\mathrm{IC}_{50}$ estimates, in the natural logarithm form, are presented in Table 1.

The combination of erythromycin with chloroquine showed a lower parasitaemia for Isolate 1 whilst quite similar rates to those of erythromycin alone were observed in the case of Isolate 2 (Figure 2). In the inferential analysis, the logistic model allowed us to consider the parallel and coincident lines as the best fitted models for Isolate 1 and 2, respectively (Table 2).
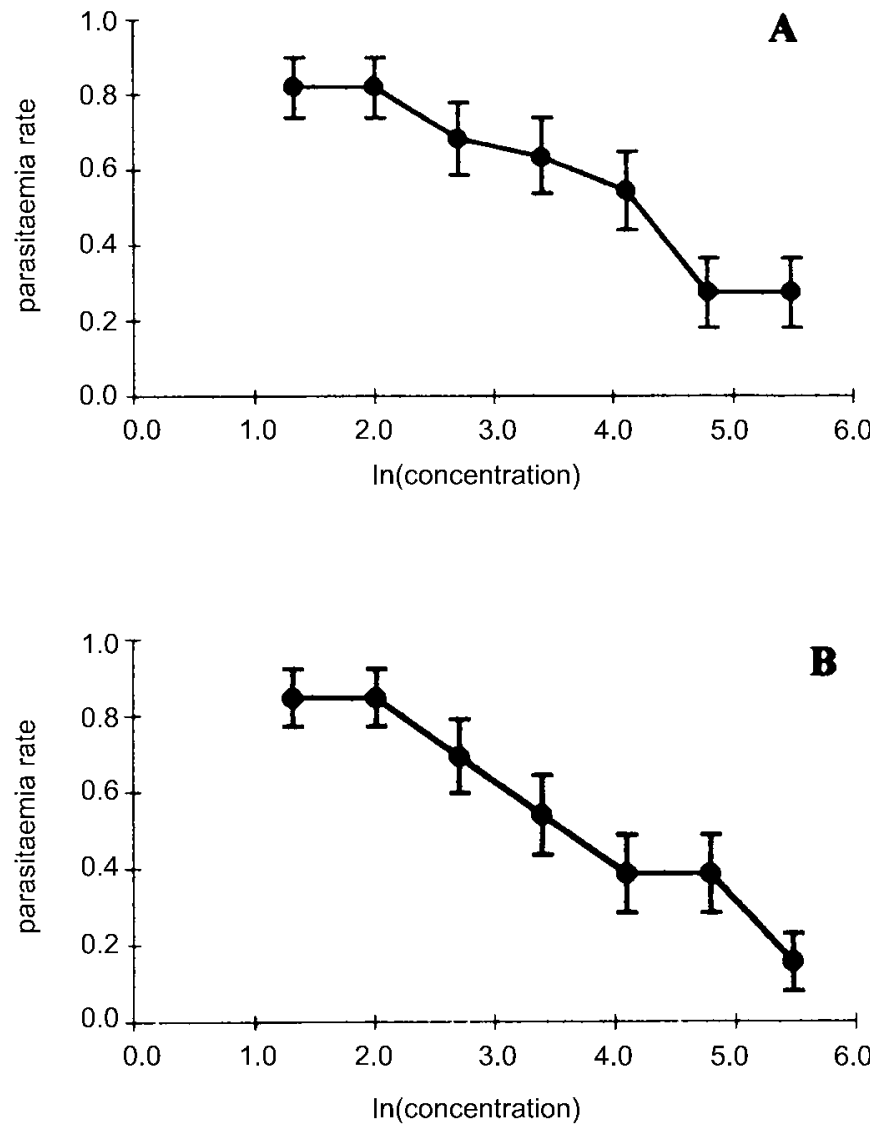

Fig. 1 - Ratios of the number of P. falciparum parasites in drug-treated cultures to the number in control cultures (parasitaemia rate) after exposure to chloroquine (A, Isolate 1 and $\mathrm{B}$, Isolate 2). 
Table 2

Fitted linear logistic model for erythromycin and its combination with chloroquine

\begin{tabular}{lccccccc}
\hline Model & Isolate & $\begin{array}{c}\text { Goodness-of- } \\
\text { fit statistic }\end{array}$ & $\begin{array}{c}\text { Degrees of } \\
\text { freedom }\end{array}$ & p-value & $\begin{array}{c}\text { Likelihood } \\
\text { ratio statistic }\end{array}$ & $\begin{array}{c}\text { Degrees of } \\
\text { freedom }\end{array}$ & p-value \\
\hline Coincident lines & 1 & 19.447 & 12 & 0.078 & & & \\
& 2 & 4.173 & 12 & 0.980 & & & \\
\hline Parallel lines & 1 & 13.836 & 11 & 0.242 & 5.611 & 1 & 0.018 \\
& 2 & 3.990 & 11 & 0.970 & 0.183 & 1 & 0.510 \\
\hline Concurrent lines (1 intercept) & 1 & 16.035 & 11 & 0.140 & 3.412 & 1 & 0.065 \\
& 2 & 3.739 & 11 & 0.977 & 0.434 & 1 & 0.669 \\
\hline Concurrent lines (2 intercepts) & 1 & 11.396 & 10 & 0.327 & 8.051 & 2 & 0.018 \\
& 2 & 3.678 & 10 & 0.961 & 0.495 & 2 & 0.781 \\
\hline
\end{tabular}
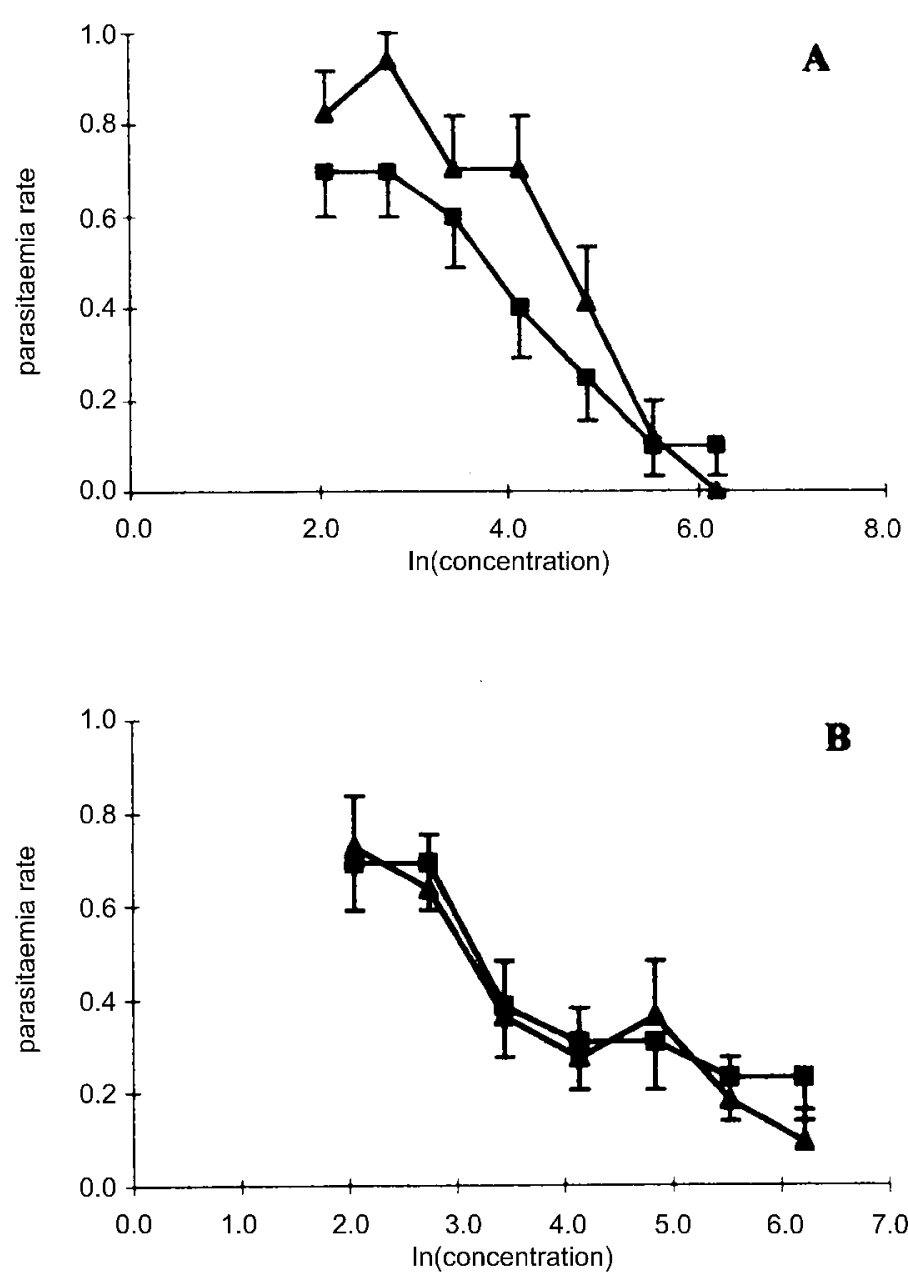

Fig. 2 - Ratios of the number of P. falciparum parasites in drug-treated cultures to the number in control cultures (parasitaemia rate) after exposure to erythromycin $(\boldsymbol{A})$ and erythromycin

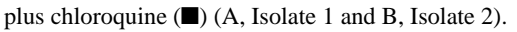

\section{DISCUSSION}

In the last decades the global malaria situation has become serious, showing a tendency to get worse. It is estimated that about 1.5 to 2.7 million people, from which 1 million children under five years old, die annually. The rate of clinical cases/year is of 300 to 500 million. Plasmodium resistance to current antimalarials, mainly the $P$.falciparum resistance to chloroquine, and Anopheles insecticide resistance are the major responsibles for this dark picture ${ }^{30,33}$. Nevertheless, chloroquine is still considered a useful drug in sensitive malaria, and this fact has been the driving force that keeps the studies on modulating resistance going on $^{30}$.

In our work a series of drugs reported as modulating agents in the literature, including erythromycin, was assayed in chloroquine resistant malaria ${ }^{23}$.

Antibiotics have been known for their antiplasmodial activity since 1940. Although these agents are less effective and slow acting when compared to chloroquine or quinine, they are alternative drugs for resistant malaria. However, considering the inherent counterindications, adverse effects and, specially, the possibility of antimicrobial resistance dissemination, public health authorities have been trying to restrict the use of antibiotics in combinations with classical antimalarials, particurlaly in areas of resistant or multi-resistant $P$. falciparum prevalence. Nowadays, WHO recommends the administration of tetracycline in combination with quinine in the treatment of resistant malaria, and doxycycline for short-term prophylaxis ${ }^{34}$. Other antiplasmodial antibiotics are erythromycin, clindamycin, rifampicin and chloramphenicol ${ }^{14,19,28,29,36}$. Also, azithromycin, a semisynthetic derivative of erythromycin, has been showing chemoprophylatic action and may be used as an option ${ }^{1,20}$ or, yet, as a substitute for doxycycline in pregnant women and in children ${ }^{34}$.

ROBINSON \& WARHURST first observed the in vitro and in vivo antimalarial activity of erythromycin, a macrolide antibiotic, in $1972^{28}$. In a dosage inferior to its toxicity limit the drug was effective against chloroquine sensitive and resistant strains of $P$. berghei. Besides, the 


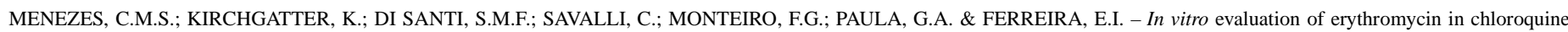
resistant Brazilian P. falciparum freshly isolates: modulating effect and antimalarial activity evidence. Rev. Inst. Med. trop. S. Paulo, 41(4): 249-253,1999.

coadministration with chloroquine was positive only against resistant strains. The potentiation was confirmed in mice infected with chloroquine resistant strains of $P$. berghei $i^{32}$ and in $P$. falciparum multidrug-resistant strains in vitro ${ }^{14,15}$. Thus, erythromycin could be an excellent choice for the treatment of chloroquine $P$. falciparum resistance, due to its lower cost and use in children and pregnant women. However, failures were observed when the combination chloroquine/erythromycin was employed in vitro in isolates of $P$. falciparum with different chloroquine sensitivities ${ }^{18}$ and in human falciparum malaria ${ }^{5,24,25}$. Meanwhile, in 1994 the possibility of antimalarial use for erythromycin was restored with the observation of in vitro potentiation effect over artemisinin in chloroquine sensitive and resistant $P$. falciparum strains. If these results persist after clinical trials, the combination could be valuable in preventing the recrudescence commonly observed with this sesquiterpene ${ }^{35}$.

In our study, erythromycin confirmed its antimalarial effect, the $\mathrm{IC}_{50}$ estimates $(73.70 \mu \mathrm{g} / \mathrm{L}$ and $27.39 \mu \mathrm{g} / \mathrm{L}$ for Isolate 1 and 2 , respectively) being near its usual concentration as an antimicrobial agent $(62.50 \mu \mathrm{g} /$ L). However, distinct effects were obtained from the inferential analysis when erythromycin was combined with chloroquine. The fitting of parallel lines for Isolate 1 suggests a positive result for the combination. In the analysis of the parasitaemia rate of erythromycin plus chloroquine (Figure 2, A), it can be observed that, in spite of the intrinsic antimalarial effect of erythromycin, the combination showed to be more effective than erythromycin or chloroquine (Figure 1, A). In fact, the combination was 2.020 times more potent than the antibiotic alone. This allow us to consider a modulating effect of erythromycin in chloroquine resistance. Unlikely, this effect was not verified for Isolate 2, coincident lines being the best fitted model. No significant statistical differences were observed in the parasitaemia rates for the combination in relation to those of erythromycin alone (Figure 2, B). This would indicate the predominance of the erythromycin antiplasmodial effect over that for chloroquine. Also, those rates seem to be lower than the observed for chloroquine (Figure $1, \mathrm{~B})$.

It is worth noting that our results are the first report about modulating agents in Brazilian P. falciparum isolates resistant to chloroquine. Erythromycin was shown to promote the modulation of one of the two isolates and, in addition, its antiplasmodial activity was confirmed for both isolates. Nevertheless, after a QSAR (quantitative structure-activity relationships) analysis developed with several drug classes, including erythromycin, the influence of the lipophilic parameter on modulating effect, as reported in the literature for this antibiotic, was not confirmed ${ }^{23}$. This deserves further studies.

\section{RESUMO}

\section{Avaliação in vitro da eritromicina em isolados brasileiros frescos do $P$. falciparum resistente à cloroquina: efeito da modulação e prova de atividade do antimalárico}

A eritromicina, agente reversor em neoplasias multi-resistentes, foi ensaiada na modulação de malária resistente à cloroquina. Empregou-se a técnica in vitro do microteste de sensibilidade em dois isolados sanguíneos frescos de Plasmodium falciparum oriundos da região Norte do Brasil. Confirmou-se o efeito antimalárico do antibiótico, o qual apresentou valores estimados de $\mathrm{IC}_{50}$ próximos à concentração usualmente empregada na terapia antimicrobiana. No entanto, efeito modulador estatisticamente significativo foi observado em apenas um dos isolados ensaiados.

\section{REFERENCES}

1. ANDERSEN, S.L.; OLOO, A.J.; GORDON, D.M. et al. - Successful double-blinded, randomized, placebo-controlled field trial of azithromycin and doxycycline as prophylaxis for malaria in Western Kenya. Clin. infect. Dis., 26: 146-150, 1998.

2. BASCO, L.K. \& LE BRAS, J. - In vitro activities of chloroquine in combination with chlorpromazine and prochlorperazine against isolates of Plasmodium falciparum. Antimicrob. Agents Chemother., 36: 209-213, 1992.

3. BENET, L.Z.; OIE, S. \& SCHWARTZ, J.B. - Design and optimization of dosage regimens: pharmacokinetic data. In: HARDMAN, J.G.; LIMBIRD, L.E.; MOLINOFF, P.B.; RUDDON, R.W. \& GILMAN, A.G. - Goodman \& Gilman's: the pharmacological basis of therapeutics. 9. ed. New York, Pergamon Press, 1996. p.1707-1792.

4. BOER, R. \& GEKELER, V. - Chemosensitizers in tumor therapy: new compounds promise better efficacy. Drugs Fut., 20: 499-509, 1995.

5. BRANDLING-BENNETT, A.D.; OLOO, A.J.; KHAN, B. \& WATKINS, W.M. - Failure of erythromycin to improve chloroquine treatment of Plasmodium falciparum in Kenya. Trans. roy. Soc. trop. Med. Hyg., 82: 363-365, 1988.

6. BRAY, P.G. \& WARD, S.A. - A comparison of the phenomenology and genetics of multidrug resistance in cancer cells and quinoline resistance in Plasmodium falciparum. Pharmacol. Therap., 77: 1-28, 1998.

7. BRESLOW, N.E. \& DAY, N.E. - Statistical methods in cancer research. 1. The analysis of case control studies. Lyon, International Agency for Research on Cancer, 1980.

8. BRUCE-CHWATT, L.J., ed. - Chemotherapy of malaria. 2. ed. Geneva, World Health Organization, 1982. p. 211-223.

9. CLARKE, E.C. - Isolation and identification of drugs in pharmaceuticals, body fluids and post-mortem material. 2. ed. London, Pharmaceutical Press, 1986. p. 588589.

10. COLLETT, D. - Modelling binary data. London, Chapman \& Hall, 1991

11. DRUGDEX(R) SYSTEM - Drug evaluation monographs. In: Micromedex CCISComputerized Chemical Information System (R), v. 73, 1992. [CDROM].

12. FOLEY, M. \& TILLEY, L. - Quinoline antimalarials: mechanisms of action and resistance and prospects for new agents. Pharmacol. Therap., 79: 55-87,1998.

13. FORD, J.M. \& HAIT, W.N. - Pharmacology of drugs that alter multidrug resistance in cancer. Pharmacol. Rev., 42: 155-199, 1990.

14. GEARY, T.G. \& JENSEN, J.B. - Effects of antibiotics on Plasmodium falciparum in vitro. Amer. J. trop. Med. Hyg., 32: 221-225, 1983.

15. GERSHON, P.D. \& HOWELLS, R.E. - Combination of the antibiotics erythromycin and tetracycline with three standard antimalarials against Plasmodium falciparum in vitro. Ann. trop. Med. Parasit., 78: 1-11, 1984.

16. HOFSLI, E. \& NISSEN-MEYER, J. - Effect of erythromycin and tumour necrosis factor on the drug resistance of multidrug-resistant cells: reversal of drug resistance by erythromycin. Int. J. Cancer, 43: 520-525, 1989.

17. HOFSLI, E. \& NISSEN-MEYER, J. - Reversal of multidrug resistance by lipophilic drugs. Cancer Res., 50: 3997-4002, 1990.

18. KHAN, B.; BRANDLING-BENNETT, A.D.; WATKINS, W.M. et al. - Plasmodium falciparum sensitivity to erythromycin and 4-aminoquinoline combinations in vitro. Ann. trop. Med. Parasit., 85: 215-222, 1991. 
19. KREMSNER, P.G.; WINKLER, S.; BRANDTS, C.; GRANINGER, W. \& BIENZLE, U. - Curing of chloroquine-resistant malaria with clindamycin. Amer. J. trop. Med. Hyg., 49: 650-654, 1993

20. KUSCHNER, R.A.; HEPPNER, D.G.; ANDERSEN, S.L. et al. - Azithromycin prophylaxis against a chloroquine-resistant strain of Plasmodium falciparum. Lancet, 343: 1396-1397, 1994

21. LE BRAS, J. \& DELORON, P. - In vitro study of drug sensitivity of Plasmodium falciparum: evaluation of a new semi-micro test. Amer. J. trop. Med. Hyg., 32: 447-451, 1983.

22. MARTIN, S.K.; ODUOLA, A.M. \& MILHOUS, W.K. - Reversal of chloroquine resistance in Plasmodium falciparum by verapamil. Science, 235: 899-901, 1987.

23. MENEZES, C.M.S. - Estudo da influência das propriedades físico-químicas na reversão da resistência do Plasmodium falciparum à cloroquina. São Paulo, 1997. (Tese de Doutoramento - Faculdade de Ciências Farmacêuticas da Universidade de São Paulo).

24. PANG, L.W.; BOUDREAU, E.F.; CHILDS, G.E. et al. - Failure of large-dose erythromycin in combination with a standard dose of chloroquine or quinine in the treatment of human falciparum malaria. Bull. Wld. Hlth. Org., 63: 739-743, 1985.

25. PHILLIPS, R.E.; LOOAREESUWAN, S.; KARBWANG, J. et al. - Failure of chloroquine/ erythromycin and chloroquine/tetracycline combinations in treatment of chloroquineresistant falciparum malaria in Eastern Thailand. Lancet, 1: 300-302, 1984.

26. RADERER, M. \& SCHEITHAUER, W. - Clinical trials of agents that reverse multidrug resistance. Cancer, 72: 3553-3563, 1993.

27. RIECKMANN, K.H.; SAX, L.J.; CAMPBELL, G.H. \& MREMA, J.E. - Drug sensitivity of Plasmodium falciparum. An in vitro microtechnique. Lancet, i: 22-23, 1978.
28. ROBINSON, B.L. \& WARHURST, D.C. - Antimalarial activity of erythromycin. Trans roy. Soc. trop. Med. Hyg., 66: 525, 1972.

29. STRATH, M.; SCOTT-FINNIGAN, T.; GARDNER, M.; WILLIAMSON, D. \& WILSON, I. - Antimalarial activity of rifampicin in vitro and in rodent models. Trans. roy. Soc. trop. Med. Hyg., 87: 211-216, 1993.

30. THE MALARIA FOUNDATION - Fact Pack. (1997). [on line 04/23/98]. Available from: www. malaria.org.

31. TRAGER, W. \& JENSEN, B.B. - Human malaria parasites in continuous culture. Science 193: $673-675,1976$

32. WARHURST, D.C.; ROBINSON, B.L. \& PETERS, W. - The chemotherapy of rodent malaria. XXIV. The blood schizontocidal action of erythromycin upon Plasmodium berghei. Ann. trop. Med. Parasit., 70: 253-258, 1976.

33. WORLD HEALTH ORGANIZATION - Division of Control of Tropical Diseases/Malaria Prevention and Control. [on line 5/26/99]. Available from: www.who.

34. WORLD HEALTH ORGANIZATION - WHO Model Prescribing Information. Drugs used in Parasitic Diseases. 2.ed. Geneva, World Health Organization, 1995. p. 24

35. YE, Z. \& VAN DYKE, K. - Interaction of artemisinin and tetracycline or erythromycin against Plasmodium falciparum in vitro. Parasite, 1: 211-218, 1994.

36. YEO, A.E. \& RIECKMANN, K.H. - The in vitro antimalarial activity of chloramphenicol against Plasmodium falciparum. Acta trop. (Basel), 56: 51-54, 1994

Received: 28 December 1998 Accepted: 03 August 1999 


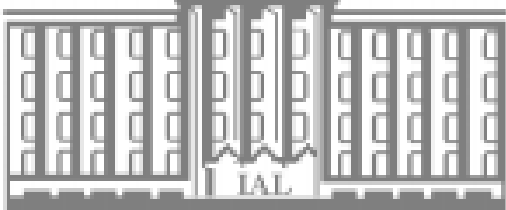

18 a 21 de Outubro de 1999

Centro de Convenções Rebouças - São Paulo/SP

Os objetivos deste evento compreendem: promover o intercâmbio técnico-científico, aproximar Instiuições parceiras, debater assuntos importantes para os Laboratórios de Saúde Pública, divulgar o trabalho realizado e ampliar o entrosamento.

\title{
TEMA CENTRAL LABORATÓRIO DE SAÚDE PÚBLICA PESQUISA E DESENVOLVIMENTO
}

\author{
03 CONFERÊNCIAS \\ 23 MESAS REDONDAS \\ 07 PALESTRAS \\ 03 PALESTRAS CULTURAIS \\ 05 CURSOS PRÉ-EVENTO \\ INFORMAÇÕES: \\ 01246-902 São Paulo, SP, Brasil \\ FAX: (0xx11) 853-3505 \\ http://www.ial.sp.gov.br/
}

Av. Dr. Arnaldo 355, térreo, sala 24

Fone: (0xx11) 3061-0111, ramal 2008

Contamos com sua participação pois acreditamos que este evento deva fazer parte do calendário de atividades técnico-científicas dos profissionais da área de saúde e da pesquisa. 